\title{
The Africa Regional SGBV Network Learning Brief Series: Learning updates from Zambia (Brief \#5)
}

Population Council

Follow this and additional works at: https://knowledgecommons.popcouncil.org/departments_sbsr-rh

Part of the Demography, Population, and Ecology Commons, Domestic and Intimate Partner Violence Commons, Family, Life Course, and Society Commons, and the International Public Health Commons How does access to this work benefit you? Let us know!

\section{Recommended Citation}

"The Africa Regional SGBV Network Learning Brief Series: Learning updates from Zambia (Brief \#5)." Nairobi: Population Council, 2016. 
Population Council

The Africa Regional SGBV Network Learning Brief Series

Fostering a Multisectoral Response to Violence Against Children in East and Southern Africa

\section{Learning Updates from Zambia (Brief \#5)}

Over a third of sexual violence cases reported at police stations and health facilities in Lusaka, Zambia from 2000-2004 involved children ages 10-14, according to a 2009 Population Council review. National gender crime statistics show that 2,234 cases of defilement were reported to the police in Zambia in 2013 alone. The Africa Regional Sexual and Gender Based Violence (SGBV) Network, set up in 2006, is addressing violence against children (VAC) in four countries. This Learning Brief is one in a series of five that share critical, initial understandings of VAC that will help us respond more effectively to the problem.

\section{Zambia Police Service and Ministry of Health}

Most sexual violence survivors seeking help at police stations in Zambia are under 18 years old. They usually go to police stations before anywhere else and often do not seek further care (e.g. at a health facility). This means that many child survivors of rape do not receive all of the help that they need.

In an attempt to ensure that child survivors receive the full range of both legal/justice and health care services, Zambia Police Service (ZPS),

FEW VICTIM SUPPORT UNIT (VSU) POLICE OFFICERS ARE TRAINED TO ATTEND TO CHILD SURVIVORS the Ministry of Health $(\mathrm{MoH})$, and the

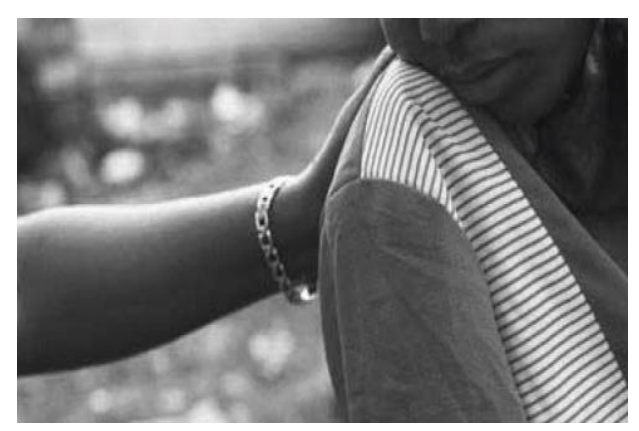
Population Council are working to operationalize Zambia's National Guidelines for the Multidisciplinary Management of Survivors of Gender-Based Violence. These three institutions have worked together since 2005 to respond to the needs of sexual violence survivors in Zambia. 


\section{What We're Already Learning}

In a formative study, Population Council and ZPS talked to child survivors, their parents/caregivers, and police and health providers involved in providing post-rape care to girls and boys. Here's what they learned:

\section{POLICE OFFICERS HAVE LIMITED KNOWLEDGE OF GUIDELINES ON MANAGEMENT OF SEXUAL VIOLENCE SURVIVORS}

- Police officers recognize that child survivors presenting at police stations require specialized approaches.

- Yet, only about a third of VSU police officers (i.e., police officers trained to provide SGBV services) had received training in the management of child survivors. All had been trained to manage adult survivors.

- Few police officers were aware of Zambia's national guidelines on the management of sexual violence survivors. However, some police officers were intuitively carrying out some of its stipulations.

- According to the national guidelines, VSU officers are meant to accompany child survivors to the health facility, ensure they receive immediate medical attention, take the child survivors' samples to the lab, and take statements from the attending health providers. These critical processes are not happening.

- Lack of police transportation is a major barrier to survivors' access to comprehensive care. Without transportation, police are unable to play their critical and mandated roles. Thus, few survivors access the care and justice they need.

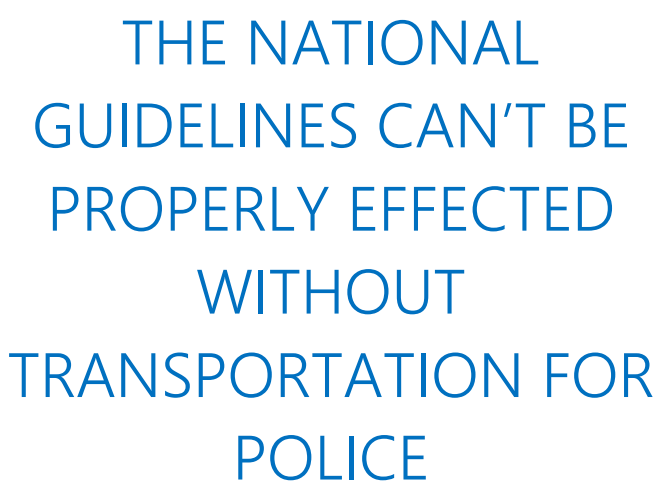




\section{What We're Doing about It}

ZPS, $\mathrm{MoH}$, and the Population Council are addressing child survivors' barriers to post-rape care in police stations and health facilities in four key ways:

- Sensitization for both police officers and health workers on the national guidelines and the mandated roles of police

- Training for VSU police officers in attending to child survivors

- Better provision and monitoring of emergency contraception (EC) at police stations

- Ensuring transport is available at police stations to enhance child survivors' access to a fuller range of services

Since 2006, the Africa Regional SGBV Network has worked to build effective responses to SGBV in low-resource settings, focusing on those who have experienced violence, as well as on violence prevention. From 2014-2017, the network is addressing the needs of two vulnerable populations - children and refugees.

(c) 2016 The Population Council, Inc.

Network Contact:

Population Council

General Accident Insurance House

Ralph Bunche Road

Nairobi, Kenya

T: +254202713480

E: info.nairobi@popcouncil.org
Population Council Contact:

No. 4 Mwaleshi Road

Lusaka Zambia

Tel: +260211295925

E: nchelwa@popcouncil.org

We gratefully acknowledge the support of the Regional Team for Sexual and Reproductive Health and Rights, Embassy of Sweden, Lusaka, Zambia.
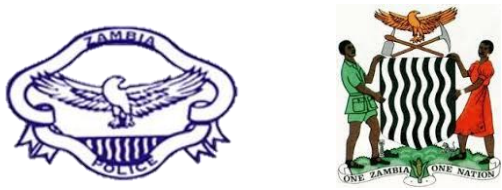